\title{
Study of Anaerobic Co-digestion of Crude Glycerol and Swine Manure for the Production of Biogas
}

\author{
Aguilar-Aguilar, F. A.;* Nelson, D. L.; Pantoja, L. A.; Santos, A. S.
}

Rev. Virtual Quim., 2017, 9 (6), 2383-2403. Data de publicação na Web: 18 de outubro de 2017

http://rvq.sbq.org.br

\section{Estudo da Codigestão Anaeróbia de Glicerol Bruto e Dejeto Suíno para Produção de Biogás}

\begin{abstract}
Resumo: Glicerol bruto e dejetos suínos são efluentes produzidos em larga escala pela indústria do biodiesel e pela suinocultura, respectivamente. O aproveitamento de tais efluentes para a produção de biogás contribuiria para o aumento da oferta de combustíveis renováveis e para a mitigação das emissões de gases de efeito estufa. Diante de tal perspectiva, o presente estudo avaliou a produção de biogás a partir da codigestão anaeróbia do glicerol bruto com o dejeto de suínos através do uso de metodologia de superfície de resposta (MSR). Foi empregado um planejamento composto central com dois fatores, quatro pontos axiais e quatro centrais. Os dois fatores avaliados foram a concentração do glicerol bruto e a concentração dos dejetos suínos, que foram examinadas na faixa de 4 a $10 \mathrm{~g} \mathrm{~L}^{-1}$ e 5 a $15 \mathrm{~g} \mathrm{~L}^{-1}$, respectivamente. Lodo ativado obtido de estação de tratamento de esgoto urbano foi usado como inóculo. A razão carbono:nitrogênio $(\mathrm{C} / \mathrm{N})$ nos reatores variou de 17,9:1 a 63,6:1. Foram observados efeitos lineares positivos e significativos $(p<0,05)$ para os fatores avaliados sobre a produção de biogás. A máxima produção de biogás observada foi de 521,5 $\mathrm{mL}$ por grama de COD inicial quando a codigestão foi conduzida com $4 \mathrm{~g} \mathrm{~L}^{-1}$ de glicerol bruto e $5 \mathrm{~g} \mathrm{~L}^{-1}$ de dejeto suíno após 35dias de processo. Os dados experimentais mostraram que o maior rendimento de biogás foi obtido com razão $\mathrm{C} / \mathrm{N}$ de 29,4 e pH próximo a 6,5.
\end{abstract}

Keywords: Biodigestão; tratamento de efluentes; glicerina bruta; biometano.

\begin{abstract}
Crude glycerol and swine manure are large-scale effluents produced by the biodiesel industry and swine breeding, respectively. The use of such effluents for the production of biogas would contribute to increase the supply of renewable fuels and to decrease emissions of greenhouse gases. The present study evaluated the production of biogas from the anaerobic co-digestion of crude glycerol with swine manure through the use of response surface methodology (RSM). A central composite design was employed with two factors, four axial points and four central points. The two factors evaluated were crude glycerol and swine manure concentrations, which were examined in the range of 4 to $10 \mathrm{~g} \mathrm{~L}^{-1}$ and 5 to $15 \mathrm{~g} \mathrm{~L}^{-1}$, respectively. Activated sludge obtained from an urban sewage treatment plant was used as inoculum. The carbon:nitrogen ratio $(\mathrm{C} / \mathrm{N})$ in the reactors ranged from 17.9:1 to 63.6:1. Positive, significant linear effects $(p<0.05)$ on biogas production were observed for the two factors evaluated. The maximum biogas production observed was $521.5 \mathrm{~mL}$ per gram of initial COD when the co-digestion was conducted with $4 \mathrm{~g} \mathrm{~L}^{-1}$ of crude glycerol and $5 \mathrm{~g} \mathrm{~L}^{-}$ ${ }^{1}$ of swine manure after 35 days. The highest biogas yield was obtained with a $\mathrm{C} / \mathrm{N}$ ratio of 29.4 and $\mathrm{pH}$ close to 6.5 .
\end{abstract}

Palavras-chave: Biodigestion; wastewater treatment; crude glycerin; biomethane.

\footnotetext{
* Universidade Federal dos Vales do Jequitinhonha e Mucuri, Programa de Pós-graduação em Biocombustíveis, Campus JK, CEP 39100-000, Diamantina-MG, Brasil.

Mfalexaguilar@gmail.com DOI: $\underline{10.21577 / 1984-6835.20170142}$
}

Rev. Virtual Quim. |Vol 9| | No. 6| |2383-2403| 


\section{Study of Anaerobic Co-digestion of Crude Glycerol and Swine Manure for the Production of Biogas}

\section{Fidel Alejandro Aguilar Aguilar, ${ }^{\mathrm{a}, *}$ David Lee Nelson, ${ }^{\mathrm{a}}$ Lilian de Araújo Pantoja, ${ }^{b}$ Alexandre Soares dos Santos ${ }^{c}$}

${ }^{a}$ Universidade Federal dos Vales do Jequitinhonha e Mucuri, Programa de Pós-graduação em Biocombustíveis, Campus JK, CEP 39100-000, Diamantina-MG, Brasil.

${ }^{\mathrm{b}}$ Universidade Federal dos Vales do Jequitinhonha e Mucuri, Instituto de Ciência e Tecnologia, Campus-JK, CEP 39100-000, Diamantina-MG, Brasil.

${ }^{\mathrm{C}}$ Universidade Federal dos Vales do Jequitinhonha e Mucuri, Departamento de Ciências Básicas, Campus JK, CEP 39100-000, Diamantina-MG, Brasil.

* falexaguilar@gmail.com

Recebido em 23 de abril de 2017. Aceito para publicação em 15 de abril de 2017

1. Introduction

2. Material and Methods

2.1. Reagents, substrates and inoculum (activated sludge)

2.2. Characterization of crude glycerol, swine manure and activated sludge

2.3. Experimental planning for anaerobic co-digestion

2.4. Determination of the volume of biogas

2.5. Analytical determination of crude glycerol and organic acids

\section{Results and Discussion}

3.1. Characterization of crude glycerol (CG), swine manure (SM) and activated sludge (inoculum)

3.2. Characterization of the initial conditions of the anaerobic co-digestion assays

3.3. Evaluation of biogas production and reduction of COD

3.4. Analysis of the response surface curve for biogas production

3.5. Evaluation of anaerobic co-digestion for the treatment of crude glycerol

3.6. Production of organic acids

\section{Conclusion}

\section{Introduction}

Anaerobic digestion is a biological process that produces biogas from biodegradable waste through the action of bacteria in the absence or restriction of oxygen. This biological process is generally used for the treatment of organic waste because of its good performance in volume reduction, 
residue stabilization and the generation of biogas and biofertilizer. ${ }^{1}$ The biogas generated by the anaerobic digestion of organic matter can contain between 45 and $70 \%$ of methane $\left(\mathrm{CH}_{4}\right)$. From the energy point of view, one kg of methane contains $55.5 \mathrm{MJ}$ of energy and is equivalent to $1.2 \mathrm{~kg}$ of LPG, $1.2 \mathrm{~kg}$ of diesel or $3.7 \mathrm{~kg}$ of wood. ${ }^{2,3}$ The anaerobic digestion of organic waste involves a series of metabolic routes (hydrolysis, acidogenesis, acetogenesis and methanogenesis) in which different types of microorganisms participate. In an environment with a $\mathrm{pH}$ between 6.5 and 7.5 and a $\mathrm{C} / \mathrm{N}$ (carbon:nitrogen) ratio between 15 and 35 , these microorganisms find the optimal conditions for the degradation of organic compounds and the production of methane. ${ }^{1,4}$

Two large niches in the world market are responsible for the generation of effluents with a large organic load, and they deserve attention from the sanitary, environmental and economic point of view. They are the swine breending and the biodiesel industry. The annual global consumption of pork is about 118 million tons. ${ }^{5}$ Brazil is the fourth largest producer of pork in the world, with a total annual production of 3.47 million tons. ${ }^{6}$ This situation results in the generation of huge quantities of swine manure (SM), which can cause environmental imbalance and damage to human health if it does not have an adequate destination for disposal. ${ }^{7}$ With regard to the biodiesel market, around 30 billion liters of this fuel are produced worldwide. $^{8}$ Brazil is the second largest biodiesel producer in the world, reaching 3.8 billion liters in $2016 .{ }^{9}$ It is estimated that approximately $10 \mathrm{~kg}$ of crude glycerol (CG) is generated for every $100 \mathrm{~kg}$ of biodiesel produced. ${ }^{3,10}$ However, as a consequence of the high cost of CG purification, its allocation to markets such as the pharmaceutical, fine chemical, cosmetics and food markets is unprofitable. ${ }^{11} \mathrm{~A}$ destination that is common and consonant with the legislation applied for the mentioned effluents would be anaerobic digestion with consequent production of biogas and biofertilizer.
Anaerobic co-digestion is a type of organic waste treatment where different substrates or effluents are mixed and processed together. ${ }^{12}$ This method is used to improve the performance in anaerobic digestion, ${ }^{13-16}$ provide a buffering effect that avoids possible inhibition of the process by alteration of $\mathrm{pH}$, furnish nutrients absent in certain effluents, or adjust the $\mathrm{C} / \mathrm{N}$ ratio to stimulate methanogenic activity and to enable a possible increase in the kinetics of biogas production. . $^{13,17-19}$

Some studies on biogas production have shown that the ideal $\mathrm{C} / \mathrm{N}$ ratio for this purpose is between 20:1 and 30:1. ${ }^{20}$ The exclusive use of SM for biogas production results in a low conversion efficiency of the organic compounds into methane because of the low $\mathrm{C} / \mathrm{N}$ ratio, which also favors the production of ammonia. ${ }^{21}$ The use of CG, which has a high relative carbon content, mixed with animal waste would adjust the $\mathrm{C} / \mathrm{N}$ ratio to more desirable values. However, co-digestion experiments with SM and CG already reported in the scientific literature did not address the $\mathrm{C} / \mathrm{N}$ parameter or explore $\mathrm{C} / \mathrm{N}$ values that were limited and below the ideal values. ${ }^{22,23}$

The evaluation of the substrates or effluents destined for biogas production should seek to clarify the synergistic effects and avoid possible antagonistic effects during anaerobic codigestion. In this sense, the response surface methodology (RSM), which uses a set of mathematical and statistical methods to evaluate the relationships between multiple independent variables and one or more responses, is a very useful tool. ${ }^{24-27}$ This study proposed to determine the influence of concentrations of crude glycerol and swine manure on the process of anaerobic co-digestion through the use of response surface methodology for the production of biogas and treatment of the effluents involved. 


\section{Material and Methods}

2.1. Reagents, substrates and inoculum (activated sludge)

All the reagents and solvents used in this work were analytical grade, P.A.-A.C.S. The analytical standards used for liquid chromatography had a minimum purity of $99 \%$. The crude glycerol used in this study was recovered after the transesterification of residual frying oil with sodium methoxide, and it was donated by the Laboratório de Produção de Biodiesel, Biolubrificantes e Biograxas of the Universidade Federal dos Vales do Jequitinhonha e Mucuri - UFVJM. Swine manure was obtained fresh from the swine facilities of the Animal Science Course of the same university. All effluents were maintained at $-4{ }^{\circ} \mathrm{C}$ until use. The biogas production was accomplished using the mixed anaerobic microflora present in the activated sludge from the effluent treatment plant in operation at the JK Campus of the UFVJM in Diamantina, MG, Brazil, as inoculum.
2.2. Characterization of crude glycerol, swine manure and activated sludge

Crude glycerol, swine manure and activated sludge were characterized in terms of chemical oxygen demand (COD), total solids content (TS), volatile solids (VS) and pH using the analytical techniques proposed by the American Public Health Association. ${ }^{28}$ All the analyses were performed in triplicate. The percentage of carbon, nitrogen and hydrogen in crude glycerol and swine manure was determined by elemental analysis (CHNS/O TruSpec ${ }^{\circledR}$ Micro Analyzer, LECO, USA).

\subsection{Experimental planning for anaerobic co-digestion}

The assays for the anaerobic co-digestion study were delimited by an experimental design using a central composite design, as presented in Table 1, containing two factors, four axial points and four central points. The factors evaluated were the concentration of crude glycerol (CG) and the concentration of swine manure (SM).

Table 1. Matrix of the central composite design $2^{2}$ containing four axial points and four central points, used to study the anaerobic co-digestion of crude glycerol with swine manure

\begin{tabular}{|c|c|c|c|c|c|c|}
\hline Variable & Factors & $\begin{array}{l}\text { Axial } \\
(-\alpha)\end{array}$ & $\begin{array}{c}\text { Minimum } \\
(-1)\end{array}$ & $\begin{array}{c}\text { Central } \\
\text { point } \\
\text { (0) }\end{array}$ & $\begin{array}{l}\text { Maximum } \\
\qquad(+1)\end{array}$ & $\begin{array}{l}\text { Axial } \\
(+\alpha)\end{array}$ \\
\hline$x_{1}$ & Crude Glycerol $\left(\mathrm{g} \mathrm{L}^{-1}\right)$ & 2.75 & 4.00 & 7.00 & 10.00 & 11.24 \\
\hline$x_{2}$ & Swine Manure $\left(\mathrm{g} \mathrm{L}^{-1}\right)$ & 2.93 & 5.00 & 10.00 & 15.00 & 17.07 \\
\hline
\end{tabular}

All the assays were performed in batch mode using $50-\mathrm{mL}$ glass cylinders and a silicone septum cap. The reactors were inoculated with $3 \mathrm{~mL}$ of activated sludge, which was equivalent to $120 \mathrm{mg}$ of volatile solids. After addition of the activated sludge, the reactors received different amounts of the CG and SM substrates to reach the concentrations determined by the experimental design detailed in Table 2. 
Table 2. Concentrations of crude glycerol (CG) and swine manure (SM) assigned by the central composite design used as planning to the anaerobic co-digestion assays

\begin{tabular}{ccc}
\hline \multirow{2}{*}{ Assay } & \multicolumn{2}{c}{ Factors } \\
\cline { 2 - 3 } & $\mathbf{C G}\left(\mathbf{g ~ L}^{-\mathbf{1}}\right)$ & $\mathbf{S M}\left(\mathbf{g ~ L}^{-\mathbf{1}}\right)$ \\
\hline $\mathbf{1}$ & 4.00 & 5.00 \\
$\mathbf{2}$ & 4.00 & 15.00 \\
$\mathbf{3}$ & 10.00 & 5.00 \\
$\mathbf{4}$ & 10.00 & 15.00 \\
$\mathbf{5}$ & 2.75 & 10.00 \\
$\mathbf{6}$ & 11.24 & 10.00 \\
$\mathbf{7}$ & 7.00 & 2.93 \\
$\mathbf{8}$ & 7.00 & 17.07 \\
$\mathbf{9}$ & 7.00 & 10.00 \\
$\mathbf{1 0}$ & 7.00 & 10.00 \\
$\mathbf{1 1}$ & 7.00 & 10.00 \\
$\mathbf{1 2}$ & 7.00 & 10.00 \\
\hline
\end{tabular}

After adding the substrates, $2.0 \mathrm{~mL}$ of nutrient solution modified from information contained in the work of Aquino et al. $(2007)^{29}$ was added (Table 3). The final volume in the reactor was adjusted to $25 \mathrm{~mL}$ with distilled water, and the $\mathrm{pH}$ was determined. The flasks were closed to maintain an anaerobic environment and incubated in a thermostated bath at $30 \pm 1.0$ ${ }^{\circ} \mathrm{C}$ until the co-digestion terminated, as indicated by the end of the production of gas. The volume of biogas produced during the fermentation process was monitored every 24 hours for a 40 day period.

Table 3. Nutrient solution used as a supplement in biogas production trials

\begin{tabular}{cccc}
\hline Macronutrient & $\begin{array}{c}\text { Concentration } \\
\left(\mathbf{m g ~ L}^{-1}\right)\end{array}$ & Micronutrient & $\begin{array}{c}\text { Concentration } \\
\left(\mathbf{m g ~ L}^{-1}\right)\end{array}$ \\
\hline $\mathrm{NH}_{4} \mathrm{Cl}$ & 1112.0 & $\mathrm{FeCl}_{3} \cdot 6 \mathrm{H}_{2} \mathrm{O}$ & 5.00 \\
$\left(\mathrm{NH}_{4}\right) \mathrm{H}_{2} \mathrm{PO}_{4}$ & 132.5 & $\mathrm{ZnCl}_{2}$ & 0.13 \\
$\left(\mathrm{NH}_{4}\right)_{2} \mathrm{HPO}_{4}$ & 44.50 & $\mathrm{MnCl}_{2} \cdot 4 \mathrm{H}_{2} \mathrm{O}$ & 1.25 \\
$\mathrm{MgCl}_{2} \cdot 6 \mathrm{H}_{2} \mathrm{O}$ & 250.00 & $\left(\mathrm{NH}_{4}\right)_{6} \mathrm{MO}_{7} \mathrm{O}_{24} \cdot 4 \mathrm{H}_{2} \mathrm{O}$ & 1.60 \\
$\mathrm{CaCl}_{2} \cdot 2 \mathrm{H}_{2} \mathrm{O}$ & 189.00 & $\mathrm{AlCl}_{3} \cdot 6 \mathrm{H}_{2} \mathrm{O}$ & 0.13 \\
$\mathrm{NaHCO}_{3}$ & 2500.00 & $\mathrm{CoCl}_{2} \cdot 6 \mathrm{H}_{2} \mathrm{O}$ & 5.00 \\
- & - & $\mathrm{NiCl}_{2} \cdot 6 \mathrm{H}_{2} \mathrm{O}$ & 13.00 \\
- & - & $\mathrm{H}_{3} \mathrm{BO}_{3}$ & 3.00 \\
- & - & $\mathrm{CuCl}_{2} \cdot 2 \mathrm{H}_{2} \mathrm{O}$ & 8.00 \\
- & - & $\mathrm{HCl}^{2}$ & 1,00 \\
\hline
\end{tabular}

The dependent variables or response factors of choice for the experimental analysis were the normalized volume of biogas produced $(\mathrm{NmL})$ and the percentage reduction of COD. Statistica 7.0 software (StatSoft) was used for the analysis of the responses to allow the description of the results by means of the adjustment to a linear mathematical model (Equation 1) or a quadratic model (Equation 2) used for the generation of response surface curves and the determination of possible interactions. ${ }^{25,30}$ Data were submitted to analysis of variance considering a level of significance $(\alpha)$ of 0.05 . The coefficient of determination ( $R^{2}$ adj) was used as a 
parameter of adequacy of the mathematical regression to the phenomena evaluated.

models generated by a least squares

$$
Y=\beta_{0}+\beta_{1} x_{1}+\beta_{2} x_{2}+\beta_{12} x_{1} x_{2}+\varepsilon \quad \text { Eq. } 1
$$

Where

$Y=$ value of the dependent variable;

$x_{1}$ e $x_{2}=$ independente variables
$B_{0}, b_{1}, b_{2}, b_{12}=$ parameters of the regression model for each variable;

$\varepsilon=$ error term (effects not explained by the model).

$$
Y=\beta_{0}+\sum_{i=1}^{k} \beta_{i} x_{i}+\sum_{i=1}^{k} \beta_{i i} x_{i}^{2}+\sum \sum_{i<j}^{k} \beta_{i j} x_{i} x_{i}+\varepsilon
$$

\section{Where}

$Y=$ value of the dependent variable;

$x_{1}$ e $x_{2}=$ independent variables;

$\beta_{0}, \beta_{i}, \beta_{i i}, \beta_{i j}=$ parameters of the regression model for each variable;

$\varepsilon=$ error term (effects not explained by the model).

For the description of the mathematical, quadratic or linear models, the parsimony principle was adopted, excluding the statistically non-significant variables from the model. In addition to the response surface methodology, the Pearson correlation coefficient $(\rho)$ was calculated crossing the $\mathrm{C} / \mathrm{N}$ (carbon mass:nitrogen mass) and $\mathrm{I} / \mathrm{S}$ (mass of VS from inoculums / mass of VS from substrates) parameters with the cumulative biogas response $(\mathrm{NmL})$, biogas by mass of the total oxygen demand ( $\mathrm{NmL}$ $\left.\mathrm{gCOD}_{\text {total }}{ }^{1}\right)$, biogas by mass of total volatile solids ( $\mathrm{NmL} \mathrm{gVS}_{\text {total }}{ }^{-1}$ ), average biogas production rate $\left(\mathrm{NmL} \mathrm{gCOD}^{-1} \mathrm{~d}^{-1}\right)$ and percentage reduction of COD variables.

\subsection{Quantification of the volume of biogas}

The gas volume gauging system was adapted from the work of Aquino et al. $(2007)^{29}$ and was composed of a $500-\mathrm{mL}$ inverted glass vial containing $3 \mathrm{~mol} \mathrm{~L}^{-1}$ solution of $\mathrm{NaOH}$, whose function was to capture $\mathrm{CO}_{2}$. The vial was adapted with a cover with an opening for the entrance of the gas produced in the anaerobic reactor and another opening for the exit of the liquid displaced by the gas (Figure 1). Measurements were performed every 24 hours after the first day of incubation by the liquid displacement method, in which the liquid displaced by the gas (Figure 1) was collected in a graduated cylinder, and the volume was then converted to the standard biogas volume ( $\mathrm{NmL})$ under normal conditions of pressure and temperature (1 atm, $0{ }^{\circ} \mathrm{C}$ ), according to the Ideal Gas Law. 


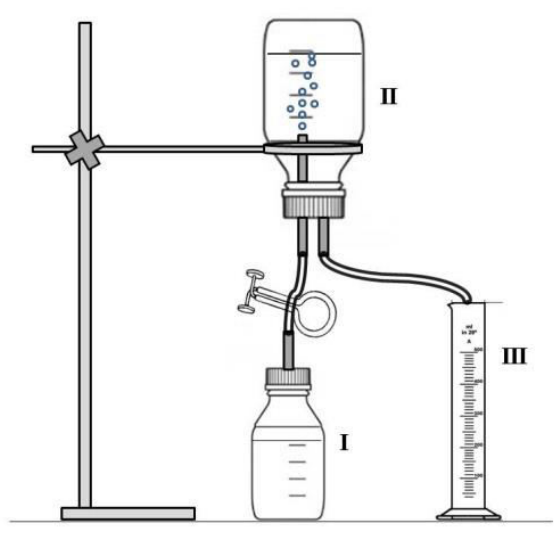

Figure 1. Apparatus for determining the volume of biogas produced: (I) reactor with exit for the biogas, (II) flask with $3 \mathrm{~mol} \mathrm{~L}^{-1} \mathrm{NaOH}$ to remove $\mathrm{CO}_{2}$ and (III) graduated cylinder for measuring the volume of liquid displaced by the biogas

2.5. Quantification of glycerol and organic acids

Glycerol and organic acids were quantified by high performance liquid chromatography (HPLC) using the Shimadzu Prominence UFLC $20 \mathrm{~A}$ system, equipped with a Rezex ROAShodex ${ }^{\mathrm{TM}}$ column (300 $\left.\times 7.5 \mathrm{~mm}\right)$, maintained at $60{ }^{\circ} \mathrm{C}$, and coupled to a UV/Vis detector for organic acid analysis at $220 \mathrm{~nm}$ and a refractive index detector in series for measuring the glycerol. The automatic injector was programmed for $5-\mu \mathrm{L}$ injections. A $0.0025 \mathrm{~mol} \mathrm{~L}^{-1} \mathrm{H}_{2} \mathrm{SO}_{4}$ solution was used as the eluent at a flow rate of $0.6 \mathrm{~mL} \mathrm{~min}^{-1}$. The identification of glycerol and organic acids, as well as their quantification, was performed with the use of external standards.

\section{Results and Discussion}

3.1. Characterization of crude glycerol (CB), swine manure (SM) and activated sludge (inoculum)

The results of the physical-chemical and elemental characterization of CG, SM and activated sludge are presented in Table 4. The alkaline $\mathrm{pH}$ of the $\mathrm{CG}$ results from the fact that it is a byproduct of transesterification of vegetable oil by homogeneous catalysis employing sodium methoxide, which results in an alkaline $\mathrm{pH}$. The $\mathrm{pH}$ value is an important indicator for evaluating the stability of anaerobic digestion systems because it affects acidogenic and methanogenic microorganisms. ${ }^{31,32}$ The concentration of volatile solids in CG was about $80 \%$ higher than that contained in SM. The percentage of carbon in CG was about $40 \%$ higher than that determined for SM. On the other hand, no significant amount of nitrogen was found in CG $(\% \mathrm{~N}<0.05)$. The percentage of carbon found in CG $(88 \%)$ is not characteristic of this effluent, which, according to Thompson and $\mathrm{He}(2006)^{33}$, can vary between 24 and $38 \%$. This excess carbon may indicate the presence of unconverted free and saponified fatty acids from the transesterification process and the presence of unrecovered methyl esters. ${ }^{34}$ SM contained $25 \%$ of proteins that would contribute as a source of nitrogen. According to Marone et al. (2015) $)^{25}$ and Dennehy et al. (2011), ${ }^{31}$ the addition of complementary nutritional components to waste co-digestion is a widely applied procedure to increase biogas production because the combination of different substrates can provide balanced nutrients, reduce costs related to $\mathrm{pH}$ control and the adjust the $\mathrm{C} / \mathrm{N}$ ratio required to optimize the biogas production process. 
Table 4. Physical-chemical and elemental characterization of crude glycerol (CG), swine manure (SM) and activated sludge (inoculum) used in the anaerobic co-digestion process

\begin{tabular}{|c|c|c|c|}
\hline \multirow{2}{*}{ Parameters } & CG & SM & Inoculum \\
\hline & \multicolumn{3}{|c|}{ Mean \pm Standard Deviation } \\
\hline $\mathrm{pH}$ & $10.30 \pm 0.10$ & $6.51 \pm 0.54$ & $6.73 \pm 0.15$ \\
\hline $\mathrm{TS}\left(\mathrm{g} \mathrm{L}^{-1}\right)$ & $870.34 \pm 0.10$ & $199.86 \pm 0.10$ & $80.95 \pm 0.11$ \\
\hline $\operatorname{VS}\left(\mathrm{g} \mathrm{L}^{-1}\right)$ & $870.10 \pm 0.10$ & $167.55 \pm 0.10$ & $40.72 \pm 0.92$ \\
\hline VS/TS (\%) & $99.97 \pm 0.10$ & $83.90 \pm 0.10$ & $50.30 \pm 0.56$ \\
\hline $\operatorname{COD}\left(\mathrm{g} \mathrm{L}^{-1}\right)$ & $1974.02 \pm 3.10$ & $137.83 \pm 1.34$ & $11.92 \pm 0.59$ \\
\hline Carbon $\left.\left(\% \mathrm{~m} \mathrm{~m}^{-1}\right)\right)$ & $88.04 \pm 0.05$ & $49.62 \pm 0.05$ & ND \\
\hline Nitrogen $\left(\% \mathrm{~m} \mathrm{~m}^{-1}\right)$ & $<0.05$ & $4.08 \pm 0.05$ & ND \\
\hline Hidrogen $\left(\% \mathrm{~m} \mathrm{~m}^{-1}\right)$ & $11.08 \pm 0.05$ & $6.50 \pm 0.05$ & ND \\
\hline Protein $\left(\% \mathrm{~m} \mathrm{~m}^{-1}\right)$ & $<0.05$ & $25.55 \pm 0.05$ & ND \\
\hline
\end{tabular}

TS: Total Solids; VS: Volatile Solids; COD: Chemical Oxygen Demand; ND: Not Determined.

3.2. Characterization of the initial conditions of the anaerobic co-digestion assays.

Although the $\mathrm{pH}$ values of the CG and SM effluents were individually significantly different (Table 4), pH values for the combination of the effluents under the different assay conditions were in the range of 7.1 to 7.6 (Table 5). No post-mixing pH adjustment was required because some authors report that this range is recommended for an efficient performance of methanogenic bacteria. ${ }^{35,36}$

The mixture of the CG and SM substrates used in this study contained 4.39 to $11.78 \mathrm{~g} \mathrm{~L}^{-}$ ${ }^{1}$ of TS; 4.07 to $11.45 \mathrm{~g} \mathrm{~L}^{-1}$ of VS; and 6.12 to $19.41 \mathrm{~g} \mathrm{~L}^{-1}$ of COD (Table 5). The $\mathrm{I} / \mathrm{S}$ ratio (mass of VS from inoculums / mass of VS from substrates) (Table 5) varied from 0.44 to 1.16 and is in line with the minimum value recommended by Labatut et al. $(2011)^{37}$ to ensure the onset of the anaerobic digestion, which, according to the authors, would be 0.5 . The $\mathrm{C} / \mathrm{N}$ ratio in the present study ranged from 17.88 to 63.63 (Table 5). The $\mathrm{C} / \mathrm{N}$ ratio reflects the relationship between carbon sources and nitrogen sources that make up the fermentation medium. An elevated $\mathrm{C} / \mathrm{N}$ ratio leads to low concentrations of free ammonia in the system. According to Zhang et al. $(2013)^{38}$ and Elsayed et al. $(2015)^{39}$, the most widely used $\mathrm{C} / \mathrm{N}$ ratios in anaerobic digestion have been in the range of 10 to 35 . There is no nitrogen $(\% \mathrm{~N}<0.05)$ in crude glycerol, and the combination with the swine manure was determinant in yielding $\mathrm{C} / \mathrm{N}$ ratios higher than 12:1. 
Table 5. Initial parameters of biogas production assays carried out with different concentrations of crude glycerol and swine manure

\begin{tabular}{|c|c|c|c|c|c|c|}
\hline \multirow[t]{2}{*}{ Assay } & \multirow{2}{*}{$\begin{array}{l}\mathrm{C} / \mathrm{N} \\
\text { Ratio } \\
\left(\mathrm{g} \mathrm{g}^{-1}\right)\end{array}$} & \multirow{2}{*}{$\begin{array}{c}\text { I/S } \\
\text { Ratio } \\
\left(\text { gVS gVS }^{-1} \text { ) }\right.\end{array}$} & $\begin{array}{c}\mathrm{COD}_{\text {total }} \\
\left(\mathrm{g} \mathrm{L}^{-1}\right)\end{array}$ & $\begin{array}{l}\mathrm{TS}_{\text {Total }} \\
\left(\mathrm{g} \mathrm{L}^{-1}\right)\end{array}$ & $\begin{array}{l}\mathbf{V S}_{\text {Total }} \\
\left(\mathrm{g} \mathrm{L}^{-1}\right)\end{array}$ & \multirow[t]{2}{*}{$\mathbf{p H}_{\text {initial }}$} \\
\hline & & & \multicolumn{3}{|c|}{ Mean \pm Standard Deviation } & \\
\hline 1 & 29.37 & 1.16 & $7.17 \pm 0.35$ & $4.48 \pm 0.13$ & $4.32 \pm 0.08$ & 7.20 \\
\hline 2 & 17.88 & 0.83 & $8.98 \pm 0.79$ & $6.48 \pm 0.29$ & $5.99 \pm 0.13$ & 7.15 \\
\hline 3 & 55.22 & 0.52 & $16.56 \pm 0.35$ & $9.70 \pm 0.39$ & $9.54 \pm 0.37$ & 7.27 \\
\hline 4 & 26.50 & 0.45 & $18.37 \pm 0.26$ & $11.70 \pm 0.80$ & $11.21 \pm 0.67$ & 7.51 \\
\hline 5 & 18.06 & 1.23 & $6.12 \pm 0.18$ & $4.39 \pm 0.37$ & $4.07 \pm 0.36$ & 7.40 \\
\hline 6 & 36.35 & 0.44 & $19.41 \pm 0.35$ & $11.78 \pm 1.15$ & $11.45 \pm 1.07$ & 7.00 \\
\hline 7 & 63.63 & 0.76 & $11.49 \pm 0.78$ & $6.68 \pm 0.70$ & $6.58 \pm 0.74$ & 7.57 \\
\hline 8 & 20.97 & 0.56 & $14.05 \pm 0.10$ & $9.50 \pm 1.07$ & $8.95 \pm 0.97$ & 7.19 \\
\hline 9 & 27.22 & 0.64 & $12.77 \pm 0.47$ & $8.09 \pm 0.27$ & $7.77 \pm 0.27$ & 7.48 \\
\hline 10 & 27.22 & 0.64 & $12.77 \pm 0.47$ & $8.09 \pm 0.27$ & $7.77 \pm 0.27$ & 7.36 \\
\hline 11 & 27.22 & 0.64 & $12.77 \pm 0.47$ & $8.09 \pm 0.27$ & $7.77 \pm 0.27$ & 7.50 \\
\hline 12 & 27.22 & 0.64 & $12.77 \pm 0.47$ & $8.09 \pm 0.27$ & $7.77 \pm 0.27$ & 7.60 \\
\hline
\end{tabular}

$\mathrm{C} / \mathrm{N}$ : mass of carbon / mass of nitrogen; I/S: mass of VS from inoculums / mass of VS from substrates; TS: Total Solids; VS: Volatile Solids COD: Chemical Oxygen Demand.

\subsection{Evaluation of biogas production and reduction of COD}

The progress curves for the production of biogas are presented in Figure 2. No lag phases were observed under any condition tested that indicated any restriction for the immediate onset of gas production. This observation led to the belief that there was a rapid adaptation of the microorganisms to the fermentation medium. The highest gas production rates were observed from the beginning of the fermentation until the sixth day, (Figure 2). This period was followed by a period in which the gas production occurred at a slower but steady rate. After the $35^{\text {th }}$ day of fermentation, all the systems entered a steady state. According to Kafle and Kim (2013), ${ }^{40}$ microbial degradation begins with substrates with a high soluble carbohydrate content, followed by proteins and subsequent degradation of lignocellulose, which is more recalcitrant. 


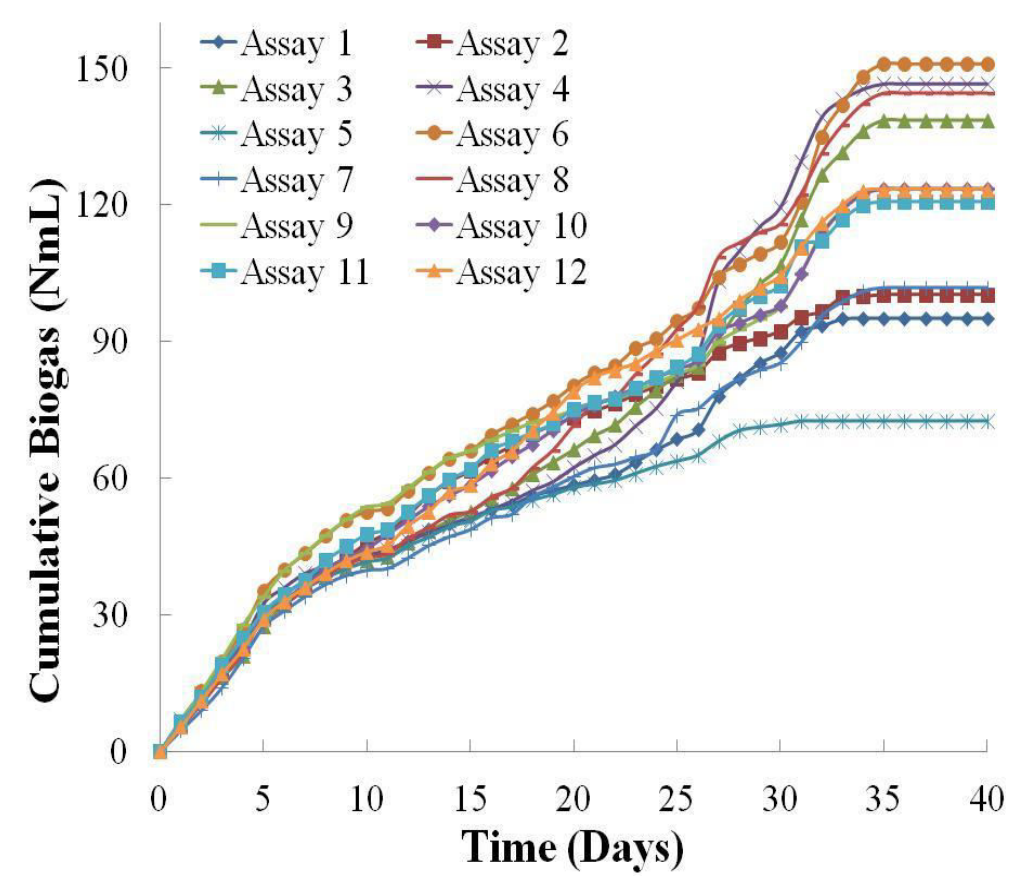

Figure 2. Profile of the biogas production in the anaerobic co-digestion assays

The biogas production was in the range 278.19 to $521.46 \mathrm{NmL}$ per gram of $\mathrm{COD}_{\text {total }}$ or 458.38 to $834.57 \mathrm{NmL}$ per gram of $\mathrm{VS}_{\text {total }}$ (Table 6). The average daily rates of biogas production ranged from 8.64 to $14.75 \mathrm{NmL}$ gCOD $^{-1} d^{-1}$ (Table 6). The best biogas yields were observed in assays 1,2 and 5 with the

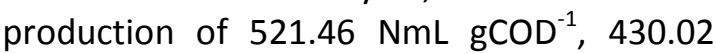
$\mathrm{NmL} \mathrm{gCOD}^{-1}$ and $473.70 \mathrm{NmL} \mathrm{gCOD}^{-1}$, respectively. Mean production rates were 14.75 $\mathrm{NmL} \mathrm{gCOD}^{-1} \mathrm{~d}^{-1}, 12.40 \mathrm{NmL}_{\mathrm{gCOD}}{ }^{-1} \mathrm{~d}^{-1}$ and $13.16 \mathrm{NmL} \mathrm{gCOD}^{-1} \mathrm{~d}^{-1}$ (Table 6). In assay 1 , the ratio of $S M$ to $C G$ was 5:4. Astals et al. $(2011)^{14}$ obtained $215 \mathrm{NmL} \mathrm{gCOD}^{-1}$ in an anaerobic codigestion process with $\mathrm{SM}$ and CG substrates mixed in a ratio of $4: 1$. Kafle and Kim $(2013)^{40}$ produced biogas from the combination of SM $(77 \%)$ and apple residues (33\%) with a yield of $398 \mathrm{NmL} \mathrm{gCOD}^{-1}$ and 505.46 NmL gCOD $^{-1}$, under mesophilic and thermophilic conditions, respectively. The results obtained in the present study under mesophilic conditions were close to those obtained by Kalfe and Kim (2013) using thermophilic conditions.

The highest yields of biogas per unit mass of $\mathrm{COD}_{\text {total }}$ were observed in trials 1,2 and 5 (Table 6), in which the $\mathrm{C} / \mathrm{N}$ ratios were 29.4 ,
17.9 and 18.1, respectively (Table 5). Assays 3,6 and 7 , which had $\mathrm{C} / \mathrm{N}$ ratios $\geq 36$ (Table $5)$, were among those with the lowest biogas yields per gram of total COD (Table 6). Several authors have reported that the optimum $\mathrm{C} / \mathrm{N}$ ratio for anaerobic digestion is in the range of 20 to $35 .{ }^{36,41,42}$ The nitrogen limitation may be a hindrance to the efficient biodigestion of crude glycerol, whereas a carbon limitation could restrict the efficiency of the conversion of swine manure to biogas. Therefore, the combined use of SM, which has a high nitrogen content $\left(4 \% \mathrm{~m} \mathrm{~m}^{-1}\right)$, with CG may have contributed to the observed values for biogas production. However, the $\mathrm{C} / \mathrm{N}$ ratio alone did not show a significant linear effect on the biogas production because the Pearson correlation coefficients ( $\rho)$ with the evaluated responses were negligible or weak $(\rho<0.5)$ (Table 7$)$. On the other hand, the $\mathrm{I} / \mathrm{S}$ ratio had a significant linear effect on biogas production (Table 7). The value of $\rho$ for the correlation of the $1 / \mathrm{S}$ ratio with biogas production per gram of $\mathrm{COD}_{\text {total }}$ was 0.925 . Therefore, the $\mathrm{I} / \mathrm{S}$ ratio exerted an effective and positive contribution to the yield of biogás per gram of COD. The same effect was observed on the biogas yield 
per gram of $\mathrm{VS}_{\text {total }}$. The effect exerted by the $\mathrm{I} / \mathrm{S}$ ratio on the accumulated biogas volume was negative $(\rho=-0.926)$. A possible explanation for this observation is that microorganisms may have been suppressed by a restriction in nutrients, which may have occurred in trials 1,2 and 5 because these trials involved the lowest CG intake.

Table 6. Final parameters from anaerobic co-digestion assays carried out with different concentrations of crude glycerol and swine manure

\begin{tabular}{ccccccc}
\hline & \multicolumn{5}{c}{ Final parameters } \\
\cline { 2 - 6 } Assays & $\begin{array}{c}\text { Accumulated } \\
\text { biogas } \\
(\mathrm{NmL})\end{array}$ & $\begin{array}{c}\text { Biogas yield } \\
(\mathrm{NmL} \\
\left.\mathrm{gCOD}_{\text {Total }}{ }^{-1}\right)\end{array}$ & $\begin{array}{c}\text { Biogas } \\
\text { production } \\
\text { rate }\left(\mathrm{NmL}^{-1}\right. \\
\left.\mathrm{gCOD}^{-1} \mathrm{~d}^{-1}\right)\end{array}$ & $\begin{array}{c}\text { Biogas yield } \\
(\mathrm{NmL} \\
\left.\mathrm{gSV}_{\text {Total }}{ }^{-1}\right)\end{array}$ & $\begin{array}{c}\text { Final } \\
\mathrm{pH}\end{array}$ & $\begin{array}{c}\text { COD } \\
\text { Reduction } \\
\left(\% \mathrm{~m} \mathrm{~m}^{-1}\right)\end{array}$ \\
\hline $\mathbf{1}$ & 93.45 & 521.46 & 14.75 & 834.57 & 6.80 & 32.74 \\
$\mathbf{2}$ & 96.55 & 430.02 & 12.40 & 595.92 & 7.00 & 53.27 \\
$\mathbf{3}$ & 126.53 & 305.62 & 9.29 & 521.76 & 6.48 & 77.38 \\
$\mathbf{4}$ & 139.24 & 303.14 & 8.87 & 475.96 & 6.65 & 70.49 \\
$\mathbf{5}$ & 72.45 & 473.70 & 13.16 & 660.37 & 6.94 & 30.18 \\
$\mathbf{6}$ & 134.98 & 278.19 & 8.64 & 458.38 & 6.54 & 79.92 \\
$\mathbf{7}$ & 95.62 & 332.91 & 9.85 & 572.63 & 6.16 & 71.31 \\
$\mathbf{8}$ & 131.18 & 373.41 & 11.41 & 552.25 & 6.46 & 60.53 \\
$\mathbf{9}$ & 113.90 & 356.76 & 10.75 & 563.14 & 6.37 & 64.01 \\
$\mathbf{1 0}$ & 113.36 & 355.06 & 10.74 & 560.46 & 6.36 & 66.16 \\
$\mathbf{1 1}$ & 112.04 & 350.94 & 10.49 & 553.96 & 6.34 & 68.32 \\
$\mathbf{1 2}$ & 116.00 & 363.31 & 10.73 & 573.48 & 6.48 & 67.14 \\
\hline
\end{tabular}

VS: Volatile Solids COD: Chemical Oxygen Demand. The standard deviation on the main response (accumulated biogas) was $1.4 \%$ based on the analysis of the center point tests $(n=4)$

Because the $\mathrm{pH}$ values measured at the end of the 40 days of fermentation varied from 6.16 to 7.00 (Table 6), it can be concluded that the mixture of the effluents contributed to the stabilization of the $\mathrm{pH}$, which suggests that no inhibition of methanogenesis resulted from the acidification of the medium.

Regarding the reduction in the organic load (COD) after the anaerobic co-digestion, the decrease in COD (Table 6) was greater in the assays where there was a higher volume of biogas, and a strong, positive Pearson correlation was observed (Table 7). Interestingly, the highest biogas yields per unit mass of $\mathrm{COD}_{\text {total }}$ (Table 6) were observed in the tests in which the decrease in organic load was the lowest, and a very strong, negative Pearson correlation was observed (Table 7). The Pearson correlation between the reduction of COD and the average rate of biogas production was also very strong and negative (Table 7 ). It is likely that the high rates of initial conversion of organic matter into biogas might have depleted some nutrients and affected the reduction in COD. It is also true that the assays with the lowest decrease in COD were those with a lower CG load. This fact might have amplified the toxicity observed in anaerobic digestion systems of swine manure with low $\mathrm{C} / \mathrm{N}$ ratios. $^{43}$ 
Table 7. Pearson correlation coefficients for the correlation between the $\mathrm{C} / \mathrm{N}$ and $\mathrm{I} / \mathrm{S}$ parameters and the response variables evaluated.

\begin{tabular}{|c|c|c|c|c|c|}
\hline Variables & $\begin{array}{c}\text { Accumulated } \\
\text { biogas } \\
\text { (NmL) }\end{array}$ & $\begin{array}{c}\text { Biogas yield } \\
\left(\mathrm{NmL} \text { gCOD }_{\text {total }}{ }^{-1}\right)\end{array}$ & $\begin{array}{l}\text { Biogas yield } \\
\left(\mathrm{NmL} \mathrm{gVS}_{\text {total }}{ }^{-1}\right)\end{array}$ & $\begin{array}{l}\text { Biogas } \\
\text { production } \\
\text { rate }(\mathrm{NmL} \\
\left.\mathrm{gCOD}^{-1} \mathrm{~d}^{-1}\right)\end{array}$ & $\begin{array}{c}\text { COD } \\
\text { Reduction } \\
\left(\% \mathrm{~m} \mathrm{~m}^{-1}\right)\end{array}$ \\
\hline C/N Ratio & 0.111 & -0.464 & -0.196 & -0.476 & 0.511 \\
\hline I/S Ratio & -0.926 & 0.925 & 0.882 & -0.462 & -0.935 \\
\hline $\begin{array}{l}\text { COD Reduction } \\
\qquad\left(\% \mathrm{~m} \mathrm{~m}^{-1}\right)\end{array}$ & 0.773 & -0.966 & -0.860 & -0.943 & 1.000 \\
\hline
\end{tabular}

$\mathrm{C} / \mathrm{N}$ : mass of carbon / mass of nitrogen; I/S: mass of VS from inoculums / mass of VS from substrates; TS: Total Solids; VS: Volatile Solids COD: Chemical Oxygen Demand.

\subsection{Response surface curve analysis for the production of biogas}

The adjustment of the polynomial model generated for the production of biogas as a function of the combination of different concentrations of $\mathrm{CG}$ and $\mathrm{SM}$ yielded a determination coefficient ( $R^{2}$ adj) of 0.90 . The ANOVA test showed that the quadratic effects and interaction of CG and SM concentrations were not significant at $p=$ 0.05 (Table 8). However, the linear effects of CG and SM concentrations were significant and positive (Figure 3 ). For these reasons, the linear regression for model adjustment that explained the behavior of gas production was used in the second moment. The adjustment of the linear model generated for the experimental data (Equation 3 ) resulted in a determination coefficient ( $R^{2}$ adj) of 0.89 , which indicated that the mathematical model was adequate for the biological phenomenon studied and that it was capable of predicting the answers within the limits evaluated for each independent variable. The correlation coefficient $\left(R^{2}\right)$ for the values observed experimentally and those predicted by the adjusted linear model was 0.91 (Figure 4).

Table 8. Analysis of variance (ANOVA) of the polynomial model obtained from biogas production data after the end of the anaerobic co-digestion process

\begin{tabular}{cccccc}
\hline Factors & SS & df & MS & F & p-value \\
\hline CG (L) & 3369.16 & 1.00 & 3369.16 & 86.37 & 0.00 \\
CG (Q) & 87.72 & 1.00 & 87.72 & 2.25 & 0.18 \\
SM (L) & 546.27 & 1.00 & 546.27 & 14.00 & 0.01 \\
SM(Q) & 8.12 & 1.00 & 8.12 & 0.21 & 0.66 \\
CG \& SM & 23.08 & 1.00 & 23.08 & 0.59 & 0.47 \\
Error & 234.06 & 6.00 & 39.01 & & \\
Total SS & 4286.06 & 11.00 & & &
\end{tabular}

SS: Sum of Squares; df: degree of freedom; MS: Mean Squares; CG: Crude Glycerol; SM: Swine Manure. 


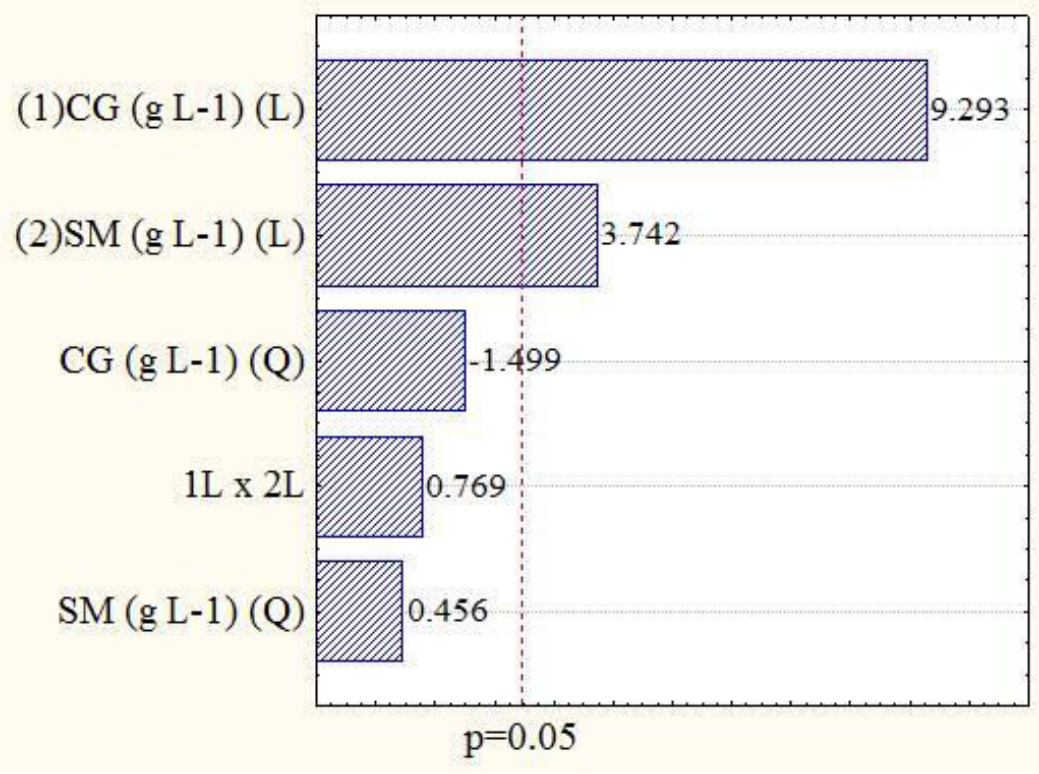

Figure 3. Pareto chart with the linear, quadratic and interaction effects of the concentration of CG and $\mathrm{SM}$ on the biogas production

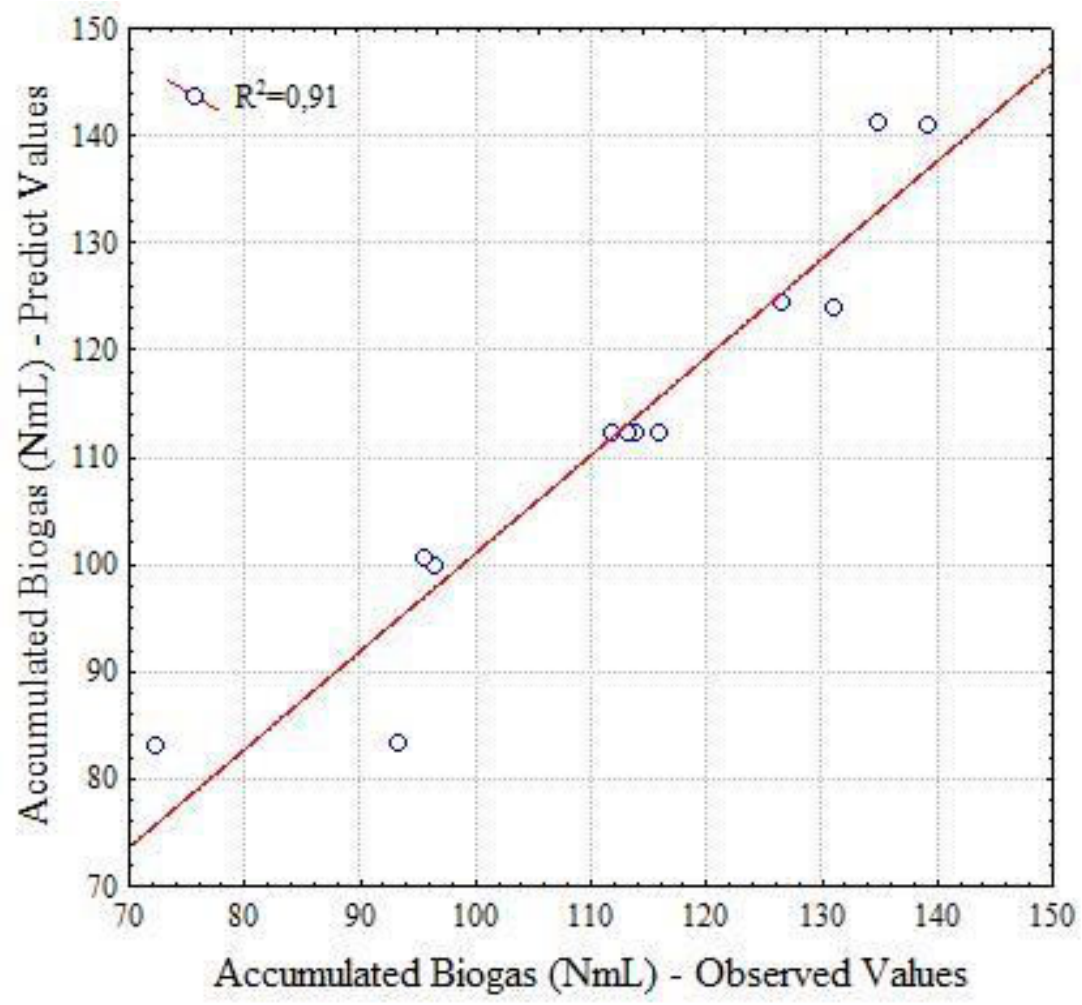

Figure 4. Chart of observed vs. predict values from accumulated biogas production at the end of anaerobic co-digestion process

$$
Y=47.70+6.84 x_{1}+1.65 x_{2} \quad \text { Eq. } 3
$$


Where

$Y$ is the biogás value $(\mathrm{NmL})$

$x_{1}$ is the CG concentration $\left(\mathrm{g} \mathrm{L}^{-1}\right)$

$x_{2}$ is the SM concentration $\left(\mathrm{g} \mathrm{L}^{-1}\right)$

In the analysis of the response surface graph generated from Equation 3 (Figure 5), was possible to observe the positive effect of DS and GB concentrations on biogas production. The highest values for biogas production were observed in the region of the graph that combines concentrations of CG and SM greater than $10 \mathrm{~g} \mathrm{~L}^{-1}$ and $15 \mathrm{~g} \mathrm{~L}^{-1}$, respectively. Production values greater than $139 \mathrm{NmL}$ of biogas were observed in this region of the graph. Because there was no maximum inflection in the surface curve, it is believed that a biogas production gain is possible with an increase in the concentration of CG and SM.

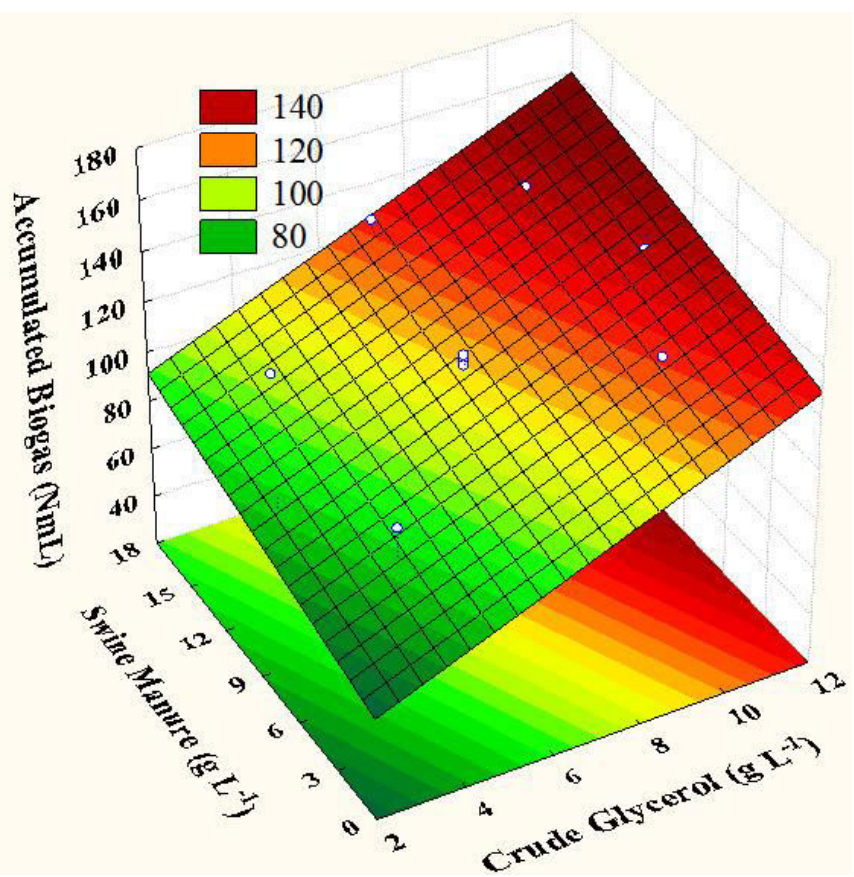

Figure 5. Surface curve adjusted to accumulated production of biogas in response to different mixtures of $C G$ and $S M$ after 35 days of anaerobic co-digestion

3.5. Evaluation of anaerobic codigestion for the treatment of crude glycerol

The treatment of the data obtained for the COD-dependent variable resulted in an adjusted model with a determination coefficient ( $R^{2}$ adj) equal to 0.91 when the linear, quadratic and interaction effects were considered. According to the Pareto graph (Figure 6), only the linear and quadratic effects of SM concentration were not significant $(p>0.05)$. The effect of interaction between $C G$ and $S M$ was negative and significant $(p<0.05)$ (Figure 6$)$. New data modeling was performed by removing the non-significant componentes, which resulted in Equation 4, with $R^{2}{ }_{\text {adj }}=0.93$. The ANOVA evaluation (Table 9 ) confirmed that the linear and quadratic effects of CG concentration and the interaction between CG and SM concentrations were significant. 


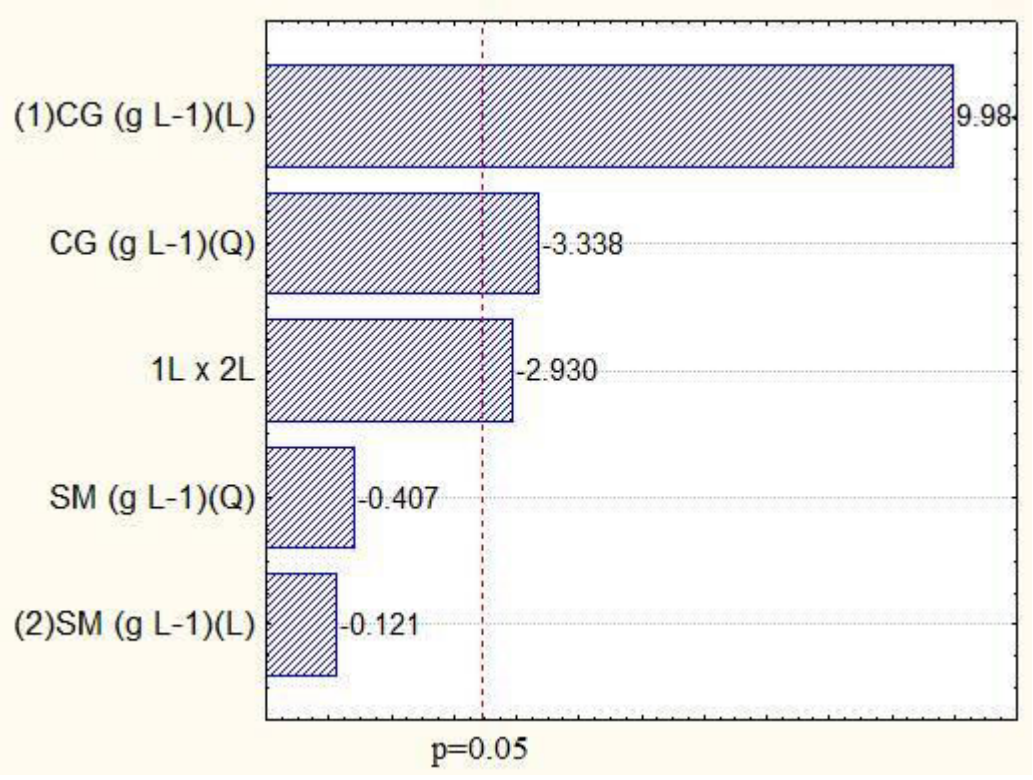

Figure 6. Pareto chart with the linear, quadratic and interaction effects of the concentration of CG and SM on the COD reduction

Table 9. Analysis of variance (ANOVA) of the polynomial model (Equation 4) obtained from COD reduction data after the end of the anaerobic co-digestion process

\begin{tabular}{cccccc}
\hline Fatores & SS & df & MS & F & p-value \\
\hline CG (L) & 2181.97 & 1.00 & 2181.97 & 129.03 & 0.00 \\
CG (Q) & 241.86 & 1.00 & 241.86 & 14.30 & 0.00 \\
CG \& SM & 187.96 & 1.00 & 187.96 & 11.11 & 0.01 \\
Erro & 135.28 & 8.00 & 16.91 & & \\
Total SS & 2750.63 & 11.00 & & &
\end{tabular}

SS: Sum of Squares; df: degree of freedom; MS: Mean Squares; CG: Crude Glycerol; SM: Swine Manure.

$$
Y=-5.48+15.3 x_{1}-0.67 x_{1}^{2}-0.04 x_{1} x_{2} \quad \text { Eq. } 4
$$

Where

$Y=$ Decrease in \%COD;

$\mathrm{x}_{1}$ e $\mathrm{x}_{2}=$ concentration of $\mathrm{CG}$ and $\mathrm{SM}$, respectively.

The effect of the SM concentration on the decrease in the COD of the effluent mixture after anaerobic co-digestion (Figure 7, obtained using Equation 4) was negligible within the assessed limits. In addition, the decrease in COD was proportional to the load of $C G$ up to the limit of $10 \mathrm{~g} \mathrm{~L}^{-1}$. Considering that the concentration of CG had a significant negative $(p<0.05)$ quadratic effect, it is probable that concentrations of CG greater than $10 \mathrm{~g} \mathrm{~L}^{-1}$ could inhibit codigestion. 


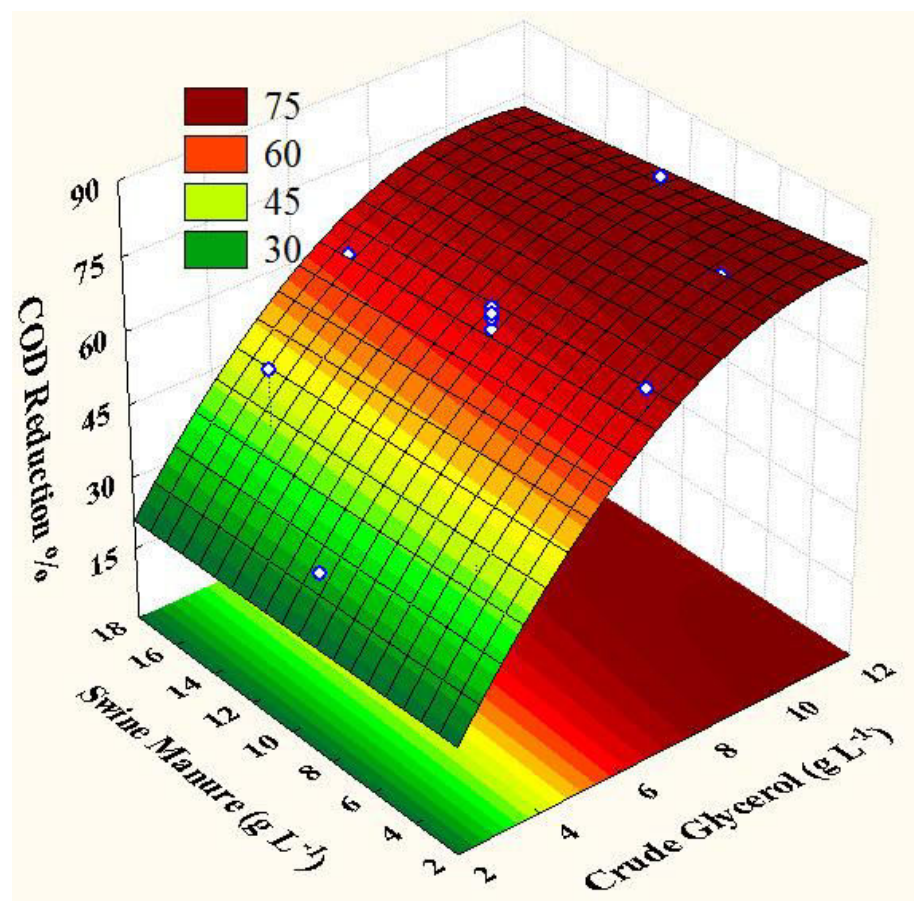

Figure 7. Surface curve adjusted to COD reduction in response to different mixtures of CG and SM after 35 days of anaerobic co-digestion

The COD decreased from $1941 \mathrm{mg} \mathrm{L}^{-1}$ to $390 \mathrm{mg} \mathrm{L}^{-1}$ under the condition of assay 6 . The greatest reduction in organic load occurred with the CG concentrations of 10 to $11.2 \mathrm{~g} \mathrm{~L}^{-1}$, independently of the SM values evaluated. In this region of the response surface curve, there was a 70.5 to $79.9 \%$ decrease in the COD values (Figure 7).

\subsection{Production of organic acids}

Volatile organic acids are key intermediate metabolites that are produced during anaerobic digestion. Acetic, propionic, butyric, isobutyric, valeric and isovaleric acids are commonly produced during the hydrolysis and acidogenesis steps. Low volatile organic acids concentrations indicate a balance between hydrolysis/acidogenesis and methanogenesis that favors methane production (Figure 8 ). The condition of assay 6 was the only condition in which the accumulation of acetic acid $\left(48 \mathrm{~g} \mathrm{~L}^{-1}\right)$ was observed after 35 days of the process. This assay stood out from the others by the greater amount of GB used (11.2 $\mathrm{g} \mathrm{L}^{-1}$ ) (Table 2 ) and by the smaller amount of biogas produced (278.2 NmL gDQO Total $^{-1}$ ) (Table 6). According to TIAN et al. $(2015)^{44}$ and Marchaim and Krause $(1993)^{45}$, a high concentration of free fat acids can inhibit methanogenic bacteria. 


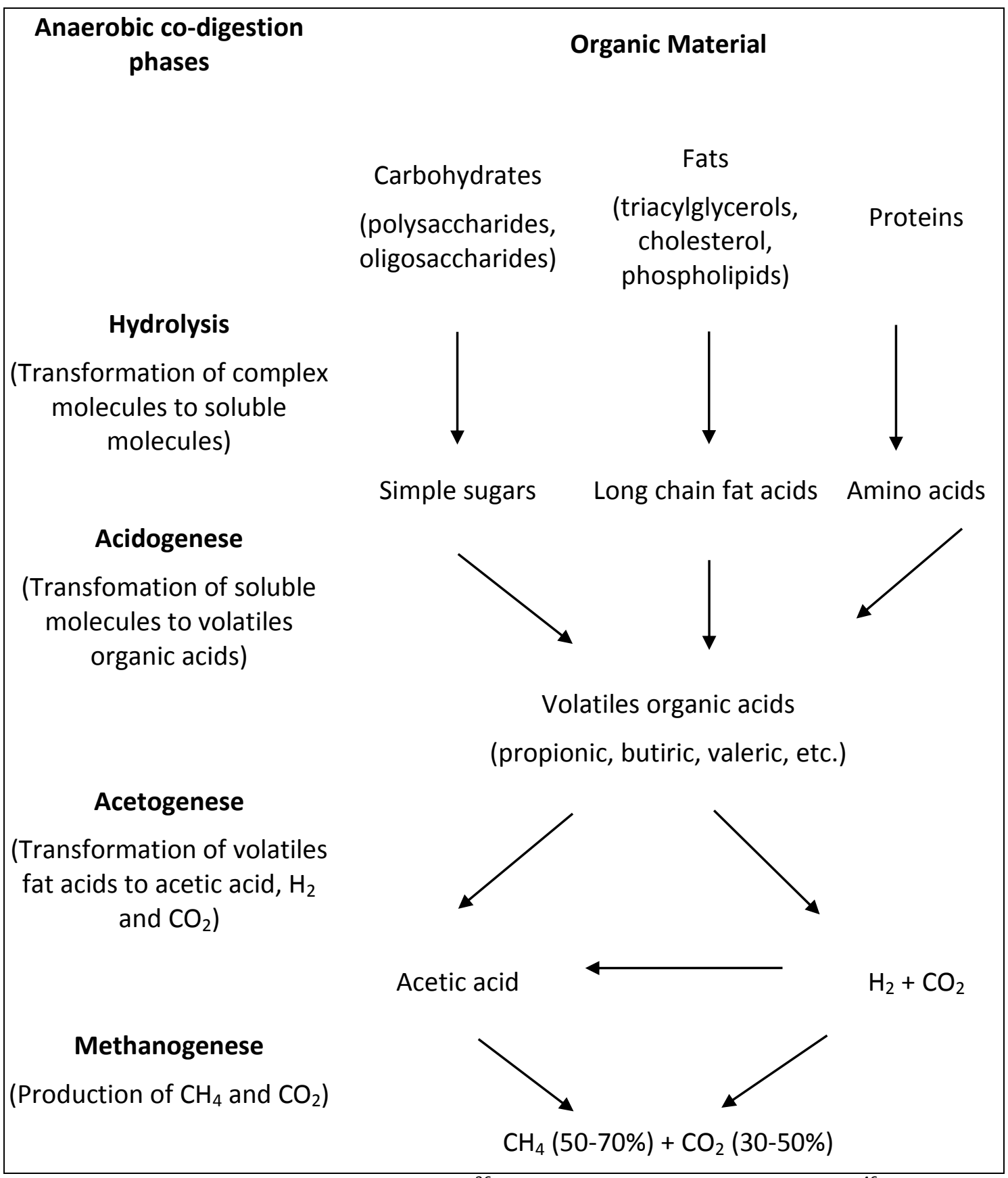

Modified from Mao et al., (2015) ${ }^{36}$ e Kondusamy e Kalamdhad, (2014)

Figure 8. Biogas production stages during conventional anaerobic biodigestion

According to some authors, ${ }^{15,17,18,23}$ propionic acid might be the strongest inhibitor of biogas production among the several free fat acids. During the digestion process, the degradation of propionic acid might be much slower than that of acetic acid, which is converted to methane and carbon dioxide (Equation 5). The propionic acid can be further degraded to acetic acid before the methane gas is generated (Equation 6, Figure 8).

$$
\mathrm{CH}_{3} \mathrm{COOH} \rightarrow \mathrm{CH}_{4}+\mathrm{CO}_{2} \quad \Delta \mathrm{G}^{0}=-31.0 \mathrm{~kJ} \mathrm{~mol}^{-1} \quad \text { Eq. } 5
$$




$$
\mathrm{CH}_{3} \mathrm{CH}_{2} \mathrm{COOH}+4 \mathrm{H}_{2} \mathrm{O} \rightarrow 2 \mathrm{CH}_{3} \mathrm{COOH}+\mathrm{CH}_{4}+\mathrm{CO}_{2}+3 \mathrm{H}_{2} \Delta \mathrm{G}^{0}=+76.1 \mathrm{~kJ} \mathrm{~mol}^{-1}
$$

The concentration of propionic acid tolerated by methanogenic bacteria is below $1 \mathrm{~g} \mathrm{~L}^{-1} \cdot 15,17,23$ The results obtained from the analysis of volatile fatty acids showed that no propionic acid existed at the end of the process. This observation suggests that, if produced at some time during the anaerobic digestion, it was produced at a concentration below that tolerated by the methanogenic bacterias or it was consumed during the generation of acetic acid and, as a final product, methane gas.

\section{Conclusion}

The results obtained in this study showed that the codigestion of the crude glycerol with the swine waste favored the production of biogas, probably because it corrected the nitrogen restriction peculiar to crude glycerol. The combination of the two effluents that yielded the best result was $4 \mathrm{~g}$ $\mathrm{L}^{-1}$ of crude glycerol and $5 \mathrm{~g} \mathrm{~L}^{-1}$ of swine manure, with the production of $521.5 \mathrm{~mL}$ of biogas per $\mathrm{g}$ of $\mathrm{COD}_{\text {total }}$ or $834.6 \mathrm{~mL}$ of biogas per $\mathrm{g}$ of $\mathrm{VS}_{\text {total }}$. The mixing of the two effluents ensured adequate buffering of the medium without further intervention. The relation between the inoculum size and the total quantity of volatile solids appeared to be a significant factor for the efficiency of biodigestion, and this fact is noteworthy.

\section{Acknowledgements}

The authors acknowledge the support of the Education and Training Alliances Program established by the consortium between the Organization of American States and the Coimbra Group of Brazilian Universities (PAEC OEA/GCUB), which allowed the author to enroll as a student of the Graduate Program in Biofuels of the Universidade Federal dos Vales do Jequitinhonha e Mucuri (UFVJM)) in 2014, and the UFVJM for the institutional doctorate scholarship granted.

\section{References}

${ }^{1}$ Appels, L.; Lauwers, J.; Degrève, J.; Helsen, L.; Lievens, B.; Willems, K.; Impea, J.; Dewil; R. Anaerobic digestion in global bio-energy production: Potential and research challenges. Renewable and Sustainable Energy 2011, 15, 4295. [CrossRef]

${ }^{2}$ Demirbas, M.; Balat, M.; Balat, H., Biowastes-to-biofuels. Energy Conversion Management 2011, 52, 1815. [CrossRef]

${ }^{3}$ Nuchdang, S.; Phalakornkule, C. Anaerobic digestion of glycerol and co-digestion of glycerol and pig manure. Journal of Environmental Management 2012, 101, 164. [CrossRef] [PubMed]

${ }^{4}$ Bouallagui, H.; Rachdi, B.; Gannoun, H.; Hamdi, M. Mesophilic and thermophilic anaerobic co-digestion of abattoir wastewater and fruit and vegetable waste in anaerobic sequencing batch reactors. Biodegradation 2009, 20, 401. [CrossRef] [PubMed]

${ }^{5}$ The Organization for Economic Cooperation and Development (OECD), Meat consumption (indicator) 2016. Available at: < $<$ https://data.oecd.org/agroutput/meatconsumption.htm>. Accessed on: 20 Abril 2017

${ }^{6}$ Associação Brasileira De Proteína Animal (ABPA). Mercado Mundial de Carne Suína. Available at: $<$ http://abpabr.com.br/setores/suinocultura/mercadomundial>. Accessed on: 31 Jan. 2017.

${ }^{7}$ Cancelier, A.; Soto, A.; Costelli, M.; Lopes, J.; Silva, A. Avaliação da produção de biogás de dejetos de suínos utilizando a metodologia de superfície de resposta. Engenharia 
Sanitaria e Ambiental 2015, 20, 209. [CrossRef]

${ }^{8}$ The Organization for Economic Cooperation and Development- Food and Agriculture Organization of the United Nations (OECD-FAO), OECD-FAO Agricultural Outlook 2016. Available at:< http://www.oecd-ilibrary.org/agricultureand-food/oecd-fao-agricultural-outlook-

2016 agr outlook-2016-en>. Accessed on: 20 Abril 2017

${ }^{9}$ Ministério de Minas e Energia (MME), Programa Nacional de Produção e Uso de Biodiesel, 2016, Available at: < http://www.mme.gov.br/programas/biodies el>. Accessed on: 20 abril 2017

${ }^{10}$ Athanasoulia, E.; Melidis, P.; Aivasidis, A. Co-digestion of sewage sludge and crude glycerol from biodiesel production. Renewable Energy 2014, 62, 73. [CrossRef]

${ }^{11}$ Kanchanasuta, S.; Sillaparassamee, 0. Enhancement of hydrogen and methane production from co-digestion of palm oil decanter cake and crude glycerol using two stage thermophilic and mesophilic fermentation. International Journal of Hydrogen Energy 2017, 42, 3440. [CrossRef]

${ }^{12}$ Horváth, I.; Tabatabaei, M.; Karimi, K.; Kumar, R. Recent updates on biogas production - a review. Biofuel Research Journal 2016, 10, 394. [CrossRef]

${ }^{13}$ Astals, S.; Batstone, D. J.; Mata-Alvarez, J.; Jensen, P. D. Identification of synergistic impacts during anaerobic co-digestion of organic wastes. Bioresource Technology 2014, 169, 421. [CrossRef] [PubMed]

${ }^{14}$ Astals, S.; Ariso, M.; Galí, A.; Mata-Alvarez,

J. Co-digestion of pig manure and glycerin: experimental and modeling study. Journal of Environmental Management 2011, 92, 1091. [CrossRef] [PubMed]

${ }^{15}$ Khalid, A.; Arshad, M.; Anjum, M.; Mahmood, T.; Dawson, L. The anaerobic digestion of solid organic waste. Waste Management 2011, 31, 1737. [CrossRef]

${ }^{16}$ Mata-Alvarez, J.; Dosta, J.; Romero-Güiza, M. S. Fonoll, X.; Peces, M.; Astals, S. A critical review on anaerobic co-digestion achievements between 2010 and 2013. Renewable and Sustainable Energy Reviews 2014, 36, 412. [CrossRef]
${ }^{17}$ Wang, X.; Yang, G.; Feng, Y.; Ren, G.; Han, $X$. Optimizing feeding composition and carbon-nitrogen ratios for improved methane yield during anaerobic codigestion of dairy, chicken manure and wheat straw. Bioresource Technology 2012, 120, 78. [CrossRef] [PubMed]

${ }^{18}$ Xie, S.; Lawlor, P.G.; Frost, J.P.; Hu, Z.; Zhan, $X$. Effect of pig manure to grass silage ratio on methane production in batch anaerobic co-digestion of concentrated pig manure and grass silage. Bioresource Technology 2011, 102, 5728. [CrossRef] [PubMed]

${ }^{19}$ Yenigün, O.; Demirel, B. Ammonia inhibition in anaerobic digestion: a review. Process Biochemistry 2013, 48, 901. [CrossRef]

${ }^{20}$ Zhang, X.; Yan, S.; Tyagi, R. D.; Surampalli, R. Y.; Valéro J. R. Energy balance of biofuel production from biological conversion of crude glycerol. Journal of Environmental Management 2016, 1, 170. [CrossRef] [PubMed]

${ }^{21}$ Das, A.; Mondal, C. Biogas Production from Co-digestion of Substrates: A Review. International Research Journal of Environment Sciences 2016, 5, 49. [Link]

${ }^{22}$ Nghiem, L. D.; Nguyen, T. T.; Manassa, P.; Fitzgerald, S. K.; Dawson, M.; Vierboom, S. Co-digestion of sewage sludge and crude glycerol for on-demand biogas production. International Biodeterioration \& Biodegradation 2014, 1, 95. [CrossRef]

${ }^{23}$ Konrad, O.; Koch, F. F.; Lumi, M.; Tonetto, J. F.; Bezama, A. Potential of Biogas Production From Swine Manure Supplemented With Glycerine Waste. Engenharia Agrícola 2014, 34, 844. [CrossRef] ${ }^{24}$ Parampalli, A.; Eskridge, K.; Smith, L.; Meagher, M.; Mowry, M.; Subramanian, A. Development of serum-free media in $\mathrm{CHO}$ DG44 cells using a central composite statistical design. Cytothecnology 2007, 54, 57. [CrossRef] [PubMed]

${ }^{25}$ Marone, A.; Varrone, C.; Fiocchetti, F.; Giussani, B.; Izzo, G.; Mentuccia, L.; Rosa, S.; Signorini, A. Optimization of substrate composition for biohydrogen production from buffalo slurry co-fermented with cheese whey and crude glycerol, using microbial 
mixed culture. International journal of Hydrogen Energy 2015, 40, 209. [CrossRef]

${ }^{26}$ Yusof, T. R. T.; Man, H. C.; Rahman, N. A. A.; Hafid, H. S. Optimization of Methane Gas Production From Co-Digestion of Food Waste and Poultry Manure Using Artificial Neural Network and Response Surface Methodology. Journal of Agricultural Science 2014, 7. [CrossRef]

${ }^{27}$ Beszédes, S.; Ábel, M.; László, Z.; Szabó, G.; Hodúr, G. Application of response surface methodology to optimize microwave sludge conditioning for enhanced biogas production. International Journal of Engineering 2011, 9, 1. [Link]

${ }^{28}$ American Public Health Association (APHA). Standard method for the examination of water and wastewater. New York: American Public Health Association, 1995. [Link]

${ }^{29}$ Aquino S. F.; Chernicharo C. A. L.; Foresti, E.; Dos Santos, M. L. F.; Monteggia. L. O. Metodologias para determinação da Atividade Metanogênica Específica (AME) em Lodos Anaeróbios, Artigo técnico 2007, 12, 192. [CrossRef]

${ }^{30}$ Bezerra, M. A.; Santelli, R. E.; Oliveira, E. P.; Villar, L. S.; Escaleira, L. A. Response surface methodology (MSR) as a tool for optimization in analytical chemistry. Talanta 2008, 76, 965. [CrossRef] [PubMed]

${ }^{31}$ Dennehy, C.; Lawlor, P. G.; Croize, T.; Jiang, Y.; Morrison, L.; Gardiner, G. E.; Zhan, X. Synergism and effect of high initial volatile fatty acid concentrations during food waste and pig manure anaerobic co-digestion. Waste Management 2016, 56, 173. [CrossRef] [PubMed]

${ }^{32}$ Glanpracha, N.; Annachhatre, A. P. Anaerobic co-digestion of cyanide containing cassava pulp with pig manure. Bioresource Technology 2016, 214, 112. [CrossRef] [PubMed]

${ }^{33}$ Thompson, J. C.; He, B. B. Characterization Of Crude Glycerol From Biodiesel Production From Multiple Feedstocks. Applied Engineering in Agriculture 2006, 22, 261. [CrossRef]
${ }^{34}$ Valerio, O.; Horvath, T.; Pond, C.; Misra, M.; Mohanty, A. Improved utilization of crude glycerol from biodiesel industries: Synthesis and characterization of sustainable biobased polyesters. Industrial Crops and Products 2015, 78, 141. [CrossRef]

${ }^{35}$ Liu, C. F. Prediction of methane yield at optimum $\mathrm{pH}$ for anaerobic digestion of organic fraction of municipal solid waste. Bioresource Technology 2008, 99, 882. [CrossRef] [PubMed]

${ }^{36}$ Mao, C.; Feng Y.; Wang, X.; Ren, G. Review on research achievements of biogas from anaerobic digestión. Renewable and Sustainable Energy Reviews 2015, 45, 540. [CrossRef]

${ }^{37}$ Labatut, R. A.; Angenent, L. T.; Scott, M. R. Biochemical methane potential and biodegradability of complex organic substrates. Bioresource Technology 2011, 102, 2255. [CrossRef] [PubMed]

${ }^{38}$ Zhang, T.; Liu, L.; Song, Z.; Ren, G.; Feng, Y., Han, X.; Gaihe, Y. Biogas production by codigestion of goat manure with three crop residues. PloS One 2013, 8, 6. [CrossRef] [PubMed]

${ }^{39}$ Elsayed, M.; Andres, Y.; Blel, W.; Gad, A. Methane production by anaerobic codigestion of sewage sludge and wheat straw under mesophilic conditions. International Journal of Scientific \& Technology Research 2015, 4, 6. [Link]

${ }^{40}$ Kafle, G. K; Kim, S. H. Anaerobic treatment of apple waste with swine manure for biogas production: batch and continuous operation. Applied Energy 2013, 103, 61. [CrossRef]

${ }^{41}$ Panichnumsin, P.; Nopharatana, A.; Ahring, B.; Chaiprasert, P. Enhanced biomethanation in co-digestion of cassava pulp and pig manure using a two phase anaerobic system. Journal Sustainable Energy and the Environment 2012, 3, 73. [Link]

${ }^{42}$ Panichnumsin, P.; Nopharatana, A.; Ahring, B.; Chaiprasert, P. Production of methane by co-digestion of cassava pulp with various concentrations of pig manure. Biomass Bioenergy2010, 34, 1117. [CrossRef]

${ }^{43}$ Fierro, J.; Martinez, E. J.; Rosas, J. G.; Fernández, R. A.; López, R.; Gomez, X. Co- 
Digestion of Swine Manure and Crude Glycerine: Increasing Glycerine Ratio Results in Preferential Degradation of Labile Compounds. Water, Air, \& Soil Pollution 2016, 227. [CrossRef]

${ }^{44}$ Tian, H.; Duan, Na.; Lin, C.; Li, X.; Zhong, M. Anaerobic co-digestion of kitchen waste and pig manure with different mixing ratios. Journal of Bioscience and Bioengineering 2015, 120, 51. [CrossRef] [PubMed]
${ }^{45}$ Marchaim, U.; Krause, C. Propionic to acetic-acid ratios in overloaded anaerobic digestion. Bioresource Technology 1993, 43, 195. [CrossRef]

${ }^{46}$ Kondusamy, D.; Kalamdhad, A. S. Pretreatment and anaerobic digestion of food waste for high rate methane production - $A$ review. Journal of Environmental Chemical Engineering 2014, 2, 1821. [CrossRef] 